\title{
Environmental impacts of barley cultivation under current and future climatic conditions
}

Dijkman, Teunis Johannes; Birkved, Morten; Saxe, Henrik; Wenzel, Henrik; Hauschild, Michael Zwicky

Published in:

Journal of Cleaner Production

Link to article, DOI:

10.1016/j.jclepro.2016.05.154

Publication date:

2017

Document Version

Peer reviewed version

Link back to DTU Orbit

Citation (APA):

Dijkman, T. J., Birkved, M., Saxe, H., Wenzel, H., \& Hauschild, M. Z. (2017). Environmental impacts of barley cultivation under current and future climatic conditions. Journal of Cleaner Production, 140, 644-653. https://doi.org/10.1016/j.jclepro.2016.05.154

\section{General rights}

Copyright and moral rights for the publications made accessible in the public portal are retained by the authors and/or other copyright owners and it is a condition of accessing publications that users recognise and abide by the legal requirements associated with these rights.

- Users may download and print one copy of any publication from the public portal for the purpose of private study or research.

- You may not further distribute the material or use it for any profit-making activity or commercial gain

- You may freely distribute the URL identifying the publication in the public portal 


\title{
Environmental impacts of barley cultivation under current and future climatic conditions
}

\author{
Teunis J. Dijkman*,a, Morten Birkved ${ }^{\mathrm{a}}$, Henrik Saxe ${ }^{\mathrm{a}}$, Henrik Wenzel ${ }^{\mathrm{b}}$, Michael Z. Hauschild ${ }^{\mathrm{a}}$
}

a) Department of Management Engineering, Technical University of Denmark, DK-2800 Kgs. Lyngby, Denmark

b) Institute of Chemical Engineering, Biotechnology and Environmental Technology, University of Southern Denmark, DK-5230 Odense M, Denmark

*) Corresponding author. Full address: Department of Management Engineering, building 424, Technical University of Denmark, DK-2800 Kgs. Lyngby, Denmark. Tel.: (+45) 4525 4886, e-mail address: tedi@dtu.dk

\begin{abstract}
The purpose of this work is to compare the environmental impacts of spring barley cultivation in Denmark under current (year 2010) and future (year 2050) climatic conditions. Therefore, a Life Cycle Assessment was carried out for the production of $1 \mathrm{~kg}$ of spring barley in Denmark, at farm gate. Both under 2010 and 2050 climatic conditions, four subscenarios were modelled, based on a combination of two soil types and two climates. Included in the assessment were seed production, soil preparation, fertilization, pesticide application, and harvest. When processes in the life cycle resulted in co-products, the resulting environmental impacts were allocated between the main product and their respective by-products using economic allocation. Impact assessment was done using the ReCiPe (H) methodology, except for toxicity impacts, which were assessed using USEtox. The results show that the impacts for all impact categories, except human and freshwater eco-toxicity, are higher when the barley is produced under climatic circumstances representative for 2050. Comparison of the 2010 and 2050 climatic scenarios indicates that a predicted decrease in barley yields under the 2050 climatic conditions is the main driver for the increased impacts. This finding was confirmed by the sensitivity analysis. Because this study focused solely on the impacts of climate change, technological improvements and political measures to reduce impacts in the 2050 scenario are not taken into account. Options to mitigate the environmental impacts are discussed.
\end{abstract}

Keywords: Life Cycle Assessment, attributional LCA, barley, climate change, future climate 
Dijkman, T. J., Birkved, M., Saxe, H., Wenzel, H., \& Hauschild, M. Z. (2017). Environmental impacts of barley cultivation under current and future climatic conditions. J ournal of Cleaner Production, 140, 644-653. DOI : $10.1016 /$ j.jclepro.2016.05.154

\section{Introduction}

Life Cycle Assessment (LCA) seeks to identify the potential environmental impacts of a product over the course of its life cycle (ISO, 2006) by assessing all inputs from and outputs to the environmental from the so-called product system. However, environmental impacts may work as a 'feedback' mechanism and in turn have consequences for future product systems. In LCA the focus usually is on how human activities affect the environment, but it must be realized that (man-made) changes to the environment also have an effect on human activities. The burdens mankind has exerted and momentarily exerts on the environment will influence future product systems. The effects of climate change on agriculture can be considered as an example of this feedback on product systems.

As a first consequence of this feedback, increasing levels of atmospheric $\mathrm{CO}_{2}$ concentrations (hereafter referred to as $\left[\mathrm{CO}_{2}\right]$ ) are known to increase grain yields (Clausen et al., 2011), resulting in lower inputs per mass unit of harvested crop. In case of barley cultivation in Denmark, yields were estimated to increase up to 20\% (Saxe, 2013). As a second consequence, a predicted temperature increase, at least under Danish circumstances, has been shown to decrease grain yields as the grain filling time is reduced (Børgesen \& Olesen, 2011). An illustration of the combination of these two effects for barley grown in Denmark was provided by Clausen et al. (2011), who compared grain yields under different environmental circumstances. Comparing grain yields under ambient and elevated (700 ppm) atmospheric $\left[\mathrm{CO}_{2}\right]$, an increase of 7.6 g/plant to 12.0 g/plant $(+56 \%)$ was observed. In contrast, barley grown under elevated $\left(+5^{\circ} \mathrm{C}\right)$ day and night temperatures showed a significantly lower yield (-27\%) compared to barley grown under ambient temperatures. When barley was grown under both elevated atmospheric $\left[\mathrm{CO}_{2}\right]$ and temperature, the yield decreased $14 \%$ compared to barley grown under ambient conditions. A third example of the effect of climate change on agriculture is that changes in the rainfall patterns, for example caused by man-made climate change (Cook et al., 2013) are expected to result in alterations in the nutrient flows from arable land, as well as to force limitations in some regions to the use of water for irrigation (Jeppesen et al., 2011). As a fourth consequence, changes in temperature and rainfall patterns may change pest populations, leaving some regions unsuitable for certain pests already present in these regions undergoing climate change, whilst new species move in to fill this ecological niche (Gregory et al., 2009). Changes in the pest species prevailing in a certain region will inevitably influence the pest management needed to maintain yields. Therefore the type and amount of pesticides applied to the arable land will be affected by climatic changes.

Changes in atmospheric $\left[\mathrm{CO}_{2}\right]$, temperature, rainfall and pest prevalence, each alone or combined will change the environmental impacts of agricultural product systems. The question is to what extent. Even though LCA is a suitable methodology to answer that question, it has, to the best of our knowledge, rarely been applied to do so. Niero et al. 
Dijkman, T. J., Birkved, M., Saxe, H., Wenzel, H., \& Hauschild, M. Z. (2017). Environmental impacts of barley cultivation under current and future climatic conditions. J ournal of Cleaner Production, 140, 644-653. DOI: $10.1016 /$ j.jclepro.2016.05.154

(2015) studied the environmental impacts of Danish spring barley under changing climate circumstances. In contrast to these authors' approach, the assumptions for the future climatic circumstances on which this paper is based, are more moderate. We worked with an atmospheric $\left[\mathrm{CO}_{2}\right]$ of $530 \mathrm{ppm}$, and an average temperature increase of $2^{\circ} \mathrm{C}$, whereas Niero et al. (2015) assume a worst-case scenario of $700 \mathrm{ppm}$ and a temperature increase of $5^{\circ} \mathrm{C}$. In addition, this study considers different soils and local climates.

This paper is thus a comparative case study of barley produced in Denmark under current and future climatic circumstances aiming at answering the following question: How do the environmental impacts of barley cultivation in Denmark change when going from the current $(400 \mathrm{ppm})$ to a future $\left(2050,530 \mathrm{ppm} \mathrm{CO}_{2}\right)$ atmospheric $\left[\mathrm{CO}_{2}\right]$ with the accompanying changes in the climatic conditions?

\section{Methods}

Life Cycle Assessment (LCA) is a comprehensive methodology to assess the environmental impacts of a product, service, or system over its entire life cycle. As defined in ISO 14040 (ISO, 2006), LCA consists of 4 phases:

1. Goal \& Scope definition, in which the product is described, and the assessment aim and method are defined;

2. Life Cycle Inventory (LCI), in which all flows between the product system and the environment are mapped and quantified,

3. Life Cycle Impact Assessment (LCIA), in which the flows quantified in the LCI are classified and characterized, and possibly normalized.

4. Interpretation, done parallel to the first three phases, in which these phases are critically reflected on, leading to changes in the goal and scope, LCI, or LCIA.

In this paper, the current section covers the goal and scope definition, as well as the LCI. The results of the LCIA are presented in section 3 and discussed in section 4.

Within LCA, two modelling approaches are generally recognized: attributional LCA (aLCA) and consequential LCA (cLCA). aLCA focuses on modeling all environmentally relevant flows of energy and materials to and from the life cycle of a product (i.e. barley), whilst the aim of cLCA is to model only those environmentally relevant flows that change as a consequence of a possible decision (Finnveden et al., 2009). aLCA was chosen as the assessment methodology. Since the primary focus of this paper is on how climate change affects the impacts of barley cultivation, and not on how the wider agricultural system changes as a consequence of changes in barley production, aLCA is the most appropriate methodology in this context. 
Dijkman, T. J., Birkved, M., Saxe, H., Wenzel, H., \& Hauschild, M. Z. (2017). Environmental impacts of barley cultivation under current and future climatic conditions. J ournal of Cleaner Production, 140, 644-653. DOI : $10.1016 /$ j.jclepro.2016.05.154

\subsection{Goals and scope}

The functional unit used here to compare barley cultivation in Denmark under current and future atmospheric $\mathrm{CO}_{2}$ concentrations ("atmospheric $\left[\mathrm{CO}_{2}\right]$ ”) is $1 \mathrm{~kg}$ of spring barley at farm gate (i.e. cradle-to-gate LCA).

The assessed product system includes all activities specifically required to produce barley: production of seeds, soil preparation (ploughing and harrowing), fertilizer and pesticide application, harvesting and drying of the harvested grains. The boundary between the product system and the environment was set as described in Dijkman et al. (2012): the field in which barley is cultivated is part of the product system, including 1 meter of soil below and the air column above the field up to 100 meters. Once a substance crosses this system border it is considered an emission to the environment.

Process multi-functionalities in the foreground system are resolved using economic allocation. We deviate from the ISO 14040 standard (ISO, 2006) recommendation of system expansion and substitution, because an important by-product of barley production, straw, has different uses, for some of which a substitute is not easily found. Moreover, relying on allocation instead allows for a straightforward sensitivity check of the product system model. There are good arguments to be made both in favor of and against economic allocation (Ardente \& Cellura, 2012). Here, it is used for two reasons. Firstly, economic data is available for all co-products to be allocated (barley and straw, pig meat and manure, and various feed crops and meals for pig production), allowing for allocation to be done consistently throughout the study. Secondly, allocating on the basis of properties such as mass and energy content do, in our opinion not reflect the motivation for production of one or more of the co-products to be allocated. Another option for allocation of agricultural products, the Cereal Unit (Brankatschk \& Finkbeiner, 2014), could not be applied for all co-products and was therefore excluded.

The product system was modelled in GaBi 4.4.142.1 (PE-LBP, 2008) using the ecoinvent 2.2 database (Ecoinvent centre, 2007).

\subsection{Scenarios}

Two scenarios were defined: a 2010 scenario representing current climatic conditions and a scenario with climatic circumstances as they are projected for Denmark by 2050. These scenarios will be referred to as the 2010 and 2050 scenarios.

In the 2010 climate scenario, the average annual temperature is $10.3^{\circ} \mathrm{C}$, with monthly averages between $2.4^{\circ} \mathrm{C}$ and $19.1^{\circ} \mathrm{C}$. Annual precipitation is $660-950 \mathrm{~mm}$, depending on the scenario (see Table 1), with June, July and August being the months with most rainfall. In the 2050 scenario it was assumed that the atmospheric $\left[\mathrm{CO}_{2}\right]$ has increased from 400 
Dijkman, T. J., Birkved, M., Saxe, H., Wenzel, H., \& Hauschild, M. Z. (2017). Environmental impacts of barley cultivation under current and future climatic conditions. Journal of Cleaner Production, 140, 644-653. DOI : $10.1016 /$ j.jclepro.2016.05.154

ppm in 2010 to 530 ppm in 2050. This is in line with the IPCC A1B scenario (IPCC, 2007), based on economic and cultural globalization, rapid economic growth and a population size which peaks in the middle of the $21^{\text {st }}$ century and decreases hereafter. In the A1B scenario, the focus is on rapid introduction of new technologies. Energy provision in these scenarios is based on a combination of fossil, non-fossil and renewable energy sources. In terms of greenhouse gas emissions, the A1B scenario falls in the middle of the range of IPCC scenarios (IPCC, 2007) used for the third and fourth assessment reports. In the fifth assessment report, published after the research reported here was designed, new scenarios were defined which could not be included. Apart from higher atmospheric $\left[\mathrm{CO}_{2}\right]$, the 2050 scenario operates with higher temperatures and an altered rainfall distribution. The temperature and rainfall distributions used were based on a Northern French temperate maritime climate dataset included in PestLCI 2.0 (Dijkman et al., 2012), under the assumption that the current climate in Northern France and Central Germany is comparable to the climate conditions expected in Denmark in 2050 (Henriksen et al., 2013). In this scenario, the average temperature is $12.3^{\circ} \mathrm{C}$ (monthly averages between $4.8^{\circ} \mathrm{C}$ and $20.2^{\circ} \mathrm{C}$ ), which is $2^{\circ} \mathrm{C}$ higher than the 2010 scenario. Moreover, more precipitation occurs in winter, and less in summer compared to the 2010 scenario: November, December and February now are the months with most precipitation. Changes in atmospheric ozone concentrations have not been included in this study.

Within both the 2010 and 2050 scenarios four sub-scenarios were defined (see Table 1). These sub-scenarios are combinations of two different soil types present in Denmark (sandy and sandy loam) and two local climates with different amounts of precipitation. The sandy soil, modelled after the Danish soil type classification numbers JB-3 and JB-4, consists of $75 \%$ sand and $10 \%$ clay, a pH of 5.1 and $1.0 \%$ organic carbon. The sandy loam soil (JB-5 and JB-6) consists of $60 \%$ sand, $11 \%$ clay and has a pH of 5.4 and contains $2.1 \%$ organic carbon. These soil types were selected, because they are the most frequently occurring soils in Denmark. Together these soils represent more than half of the Danish surface area: JB-3 and JB-4 soils cover $28 \%$ of the Danish surface area, JB-5 and JB-6 cover $24.5 \%$ (Mortensen, 1986). Sandy soils are found mostly in northern and western Jutland, sandy loam soils are found in eastern Jutland and on the islands (Mortensen, 1986). The main difference between the climates is the annual amount of precipitation: $650 \mathrm{~mm} / \mathrm{y}$ and $950 \mathrm{~mm} / \mathrm{y}$ in the dry and wet scenario respectively.

Table 1: Scenarios for barley cultivation

\begin{tabular}{|c|c|c|c|c|c|c|c|c|}
\hline \multirow[t]{3}{*}{ Main scenario } & \multicolumn{8}{|c|}{ Subscenario } \\
\hline & \multicolumn{2}{|c|}{1} & \multicolumn{2}{|c|}{2} & \multicolumn{2}{|c|}{3} & \multicolumn{2}{|c|}{4} \\
\hline & soil & climate & soil & climate & soil & climate & soil & climate \\
\hline $\begin{array}{l}2010 \\
2050\end{array}$ & sandy & wet & sandy & dry & $\begin{array}{l}\text { sandy } \\
\text { loam }\end{array}$ & wet & $\begin{array}{l}\text { sandy } \\
\text { loam }\end{array}$ & dry \\
\hline
\end{tabular}


Dijkman, T. J., Birkved, M., Saxe, H., Wenzel, H., \& Hauschild, M. Z. (2017). Environmental impacts of barley cultivation under current and future climatic conditions. Journal of Cleaner Production, 140, 644-653. DOI : $10.1016 /$ j.jclepro.2016.05.154

\subsection{Life Cycle Inventory Analysis}

\subsubsection{Yield}

Danish spring barley grain yields in the 2010 main scenarios were approximately $4250 \mathrm{~kg}$ dry material (DM)/ha on a sandy soil and $4850 \mathrm{~kg} \mathrm{DM} / \mathrm{ha}$ on sandy loam soils. The crop was assumed to be grown in combination with a catch crop on both soils (Hamelin et al., 2012). Yields in the 2050 main scenarios are assumed to be $10 \%$ lower, based on interpolations from the data by Doltra et al. (2012). This decrease reflects the combined effects of increased atmospheric $\left[\mathrm{CO}_{2}\right]$ and temperature.

\subsubsection{Fertilization and nutrient emissions}

In this study, nitrogen, phosphorous and potassium fertilization were taken into account, assuming that half the crop’s $\mathrm{N}$ demand was fulfilled by application of pig manure. The composition of this manure was based on Hamelin (2013). Based on sales statistics for fertilizers in Denmark (Nielsen et al., 2011), the amount of P and K not met with manure were modelled to be supplied by application of diammonium phosphate and potassium chloride. Calcium ammonium nitrate (CAN) was modelled to supplement manure and diammonium phosphate as $\mathrm{N}$ fertilizer.

The fertilizer inputs per hectare for the 2050 scenarios were assumed to be the same as those for the 2010 scenarios. The level of $\mathrm{N}$ fertilization is currently not determined by the plant's need, but rather by the levels of $\mathrm{N}$ emissions that are considered acceptable in terms of freshwater emissions (Olesen, personal communication, 9 April 2013). The fertilization level is therefore mainly a political decision, and hence outside this paper's scope. Table 2 shows the amounts of fertilizer applied to each of the soil types modeled in the sub-scenarios presented in Table 1. It was assumed that the synthetic fertilizer is transported $50 \mathrm{~km}$ by truck from a regional storehouse to the farmer.

Table 2: Fertilizer recommendations and amounts applied

\begin{tabular}{|c|c|c|c|c|c|c|}
\hline \multirow[t]{3}{*}{ Fertilizer demand and sources } & \multicolumn{6}{|c|}{ Soil type } \\
\hline & \multicolumn{3}{|c|}{ sandy } & \multicolumn{3}{|c|}{ sandy loam } \\
\hline & $\mathrm{N}$ & $\mathrm{P}$ & $\mathrm{K}$ & $\mathrm{N}$ & $\mathrm{P}$ & $\mathrm{K}$ \\
\hline Fertilizer requirements $^{1}$ & 109 & 22 & 45 & 97 & 22 & 45 \\
\hline Fertilizer sources: & & & & & & \\
\hline Manure & $54.5(72.7)^{2}$ & 17.2 & 40.9 & $48.5(64.7)^{2}$ & 15.3 & 35.4 \\
\hline Diammonium phosphate & 4.3 & 4.8 & - & 6.0 & 6.7 & - \\
\hline Calcium ammonium nitrate & 50.2 & - & - & 42.5 & - & - \\
\hline Potassium chloride & - & - & 4.1 & - & - & 8.6 \\
\hline
\end{tabular}

1: Danish Ministry of Food, Agriculture and Fisheries (2009).

2: Danish farmers are allowed to apply an estimated 75\% efficiency of pig manure in replacing mineral fertilizer, and can hence apply 133\% of the recommended dose (Danish Ministry of Food, Agriculture and Fisheries (2009). 
Dijkman, T. J., Birkved, M., Saxe, H., Wenzel, H., \& Hauschild, M. Z. (2017). Environmental impacts of barley cultivation under current and future climatic conditions. J ournal of Cleaner Production, 140, 644-653.

DOI: $10.1016 /$ j.jclepro.2016.05.154

Lime (850 kg/ha) was assumed to be applied once every 5 years in order to maintain soil $\mathrm{pH}$ and yields (Hamelin, 2013). An application of $170 \mathrm{~kg} / \mathrm{ha}$ annually was hence allocated to the barley production for all scenarios. Here, an estimated $200 \mathrm{~km}$ transport from plant to farm was assumed.

Emissions of nitrogen-containing gaseous conversion products of both mineral fertilizers and manure were calculated using the emission factors given in Hamelin (2013). Leaching of nitrate to water was modelled by Hamelin (personal communication, 19 April 2013). In accordance with the emission factors presented by this author, it was assumed that 5 $\%$ of $\mathrm{P}$ surpluses and $0 \%$ of $\mathrm{K}$ surpluses are emitted to surface freshwater recipients. $\mathrm{K}$ emissions are set to $0 \%$ of the surplus since these do not contribute to any of the impact categories considered. A fertilizer surplus is here defined as the difference between the amount of mineral applied and the amount of mineral contained in the parts of the crop removed from the field. The applied emission factors are summarized in Table 3.

For the 2050 scenarios the 2010 emissions factors were considered representative and hence applied. Nitrate leaching to water was based on interpolation of $\mathrm{N}$ leaching results from Doltra et al. (2012), showing that as a consequence of the predicted change in precipitation patterns, emissions will increase with $2 \%$ and $50 \%$ in 2050 for sandy and sandy loam soils, respectively.

Table 3: Emission flows from fertilizer during barley cultivation, 2010 scenario

\begin{tabular}{|c|c|c|}
\hline \multicolumn{3}{|c|}{ N flows } \\
\hline \multicolumn{3}{|c|}{$\mathrm{NH}_{3}$ to air (kg NH $\mathrm{NH}_{3}-\mathrm{N} / \mathrm{kg} \mathrm{N}$ applied) } \\
\hline - from mineral fertilizers & 0.020 & \\
\hline \multirow[t]{2}{*}{ - from manure } & 0.12 & \\
\hline & 0.004 & during application, manure only \\
\hline \multicolumn{3}{|c|}{$\mathrm{N}_{2} \mathrm{O}$ to air (kg $\mathrm{N}_{2} \mathrm{O}-\mathrm{N} / \mathrm{kg} \mathrm{N}$ applied) } \\
\hline - from mineral fertilizers & 0.01 & \\
\hline - from manure & 0.01 & \\
\hline - from decaying crops & 0.01 & \\
\hline \multicolumn{3}{|c|}{$\mathrm{NO}_{\mathrm{x}}$ to air (only NO) (kg NO-N/kg N) } \\
\hline - from fertilizer & 0.011 & per kg N applied \\
\hline - from decaying crop residues & 0.007 & per kg N present \\
\hline \multicolumn{3}{|l|}{$\mathrm{NO}_{3}^{-}$to water $\left(\mathrm{kg} \mathrm{NO}_{3}^{-}-\mathrm{N} / \mathrm{ha} / \mathrm{y}\right)$} \\
\hline - wet climate & $31 / 26$ & on sand resp. sandy loam soil \\
\hline - dry climate & $25 / 21$ & on sand resp. sandy loam soil \\
\hline \multicolumn{3}{|c|}{ 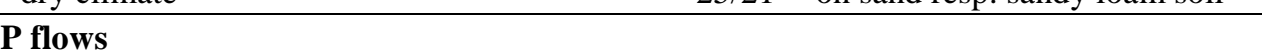 } \\
\hline $\mathrm{P}$ to water & \multicolumn{2}{|c|}{$5 \%$ of surplus } \\
\hline \multicolumn{3}{|l|}{ K flows } \\
\hline K to water & \multicolumn{2}{|c|}{$0 \%$ of surplus } \\
\hline
\end{tabular}


Dijkman, T. J., Birkved, M., Saxe, H., Wenzel, H., \& Hauschild, M. Z. (2017). Environmental impacts of barley cultivation under current and future climatic conditions. Journal of Cleaner Production, 140, 644-653. DOI : $10.1016 /$ j.jclepro.2016.05.154

\subsubsection{Manure}

Manure was modelled as a by-product from pig farming. The inputs to the pig production considered are feed, and heat, electricity and tap water for pig farm operation. These inputs are presented in Table 4. The amount of feed is based on a feed conversion ratio (i.e. the ratio between food consumed and weight gain) of 1.92 for weaners (0-30 kg) and 2.82 for finishers (30-100 kg, Danish Agriculture and Food Council, 2011). The feed composition for the 2010 and 2050 scenarios were obtained from Saxe (personal communication, 6 May 2013). The feed composition under the 2050 climatic scenarios is based on forecasted changes in feed crop composition that alter the applicability of the crop as a pig feed ingredient. The most marked changes were the decrease in wheat (-5\% compared to 2010), and the increased use of soy meal (+23\%). Feed constituents making up less than $0.6 \%$ of the feed mass were cut off, resulting in $97.4 \%$ of the feed mass being included.

Table 4: Inputs for pig farming, per $\mathrm{kg}$ pig live weight at the farm gate

\begin{tabular}{rcc}
\hline Input & \multicolumn{2}{c}{ Mass } \\
\hline Feed (kg) & \multicolumn{2}{c}{2.55} \\
Feed composition & $(2010)$ & $(2050)$ \\
wheat & 0.48 & 0.46 \\
barley & 0.25 & 0.25 \\
soy meal & 0.092 & 0.11 \\
rape meal & 0.068 & 0.068 \\
sunflower meal & 0.042 & 0.042 \\
beet molasses & 0.017 & 0.020 \\
PFAD oil & 0.013 & 0.013 \\
Lime & 0.012 & 0.012 \\
Electricity (MJ) & 0.42 \\
Heat (MJ) ${ }^{1}$ & 0.47 \\
Tap water (MJ) ${ }^{1}$ & 0.35 \\
\hline 1: Data from Reckmann (2013) \\
2.3.4 Pesticide application and emissions
\end{tabular}

Pesticides used and application dates for spring barley production in the 2010 and 2050 scenarios were taken from Henriksen et al. (2013). These authors based their 2050 scenarios on current crop management practice in Central Germany and Northern France, because these areas currently have a climate similar to the climate modelled for Denmark in 2050 in terms of temperature conditions. In this study, we follow the assumption made in Henriksen et al. (2013) that the occurrence and intensity of pests in Central Germany and Northern France is a good approximation of the situation in Denmark in similar climatic circumstances. Table 5 lists the pesticides used in this study, as well as their application dates. Based on the current practice in Germany and France, an application of insecticide on loamy soil is omitted in the 2050 scenarios (Henriksen et al., 2013). Since the season for crop growth in Denmark is expected to start earlier under future climate conditions, the pesticides used for spring barley production will also be applied earlier. 
Dijkman, T. J., Birkved, M., Saxe, H., Wenzel, H., \& Hauschild, M. Z. (2017). Environmental impacts of barley cultivation under current and future climatic conditions. Journal of Cleaner Production, 140, 644-653. DOI : $10.1016 /$ j.jclepro.2016.05.154

Table 5: Pesticides applied for spring barley cultivation

\begin{tabular}{llcccc}
\hline Product name & Active ingredient & \multicolumn{2}{c}{ Dose g a.i./ha $^{1}$} & \multicolumn{2}{c}{ Application date } \\
& & 2010 & 2050 & 2010 & 2050 \\
\hline Oxitril (herbicide) & Thifensulfuron methyl & 2.64 & 2.64 & May 1 & April 20 \\
& Tribenuron methyl & 1.34 & 1.34 & & \\
Comet (fungicide) & Pyraclostrobin & 62.5 & 62.5 & May 10 & May 5 \\
Opus (fungicide) & Epoxiconazole & 31.3 & 31.3 & May 10 & May 5 \\
Karate (insecticide) $^{2}$ & $\lambda$-cyhalotrin & 3.75 & - & June 1 & - \\
\hline
\end{tabular}

1: Calculated from the volumes listed by Henriksen et al. (2013) and product labels

2: Only applied on loamy soils in current practice (Henriksen et al., 2013)

Pesticide emissions to air and surface water were calculated using PestLCI 2.1, a modified version of PestLCI 2.0 (Dijkman et al., 2012). This model is suitable for our purposes because it allows for soil and climate-specific pesticide emission patterns. Modifications of the PestLCI model include a reworked approach towards macropore flow as described in Dijkman et al. (2014) and new soil profiles of typical Danish sandy (JB-3 and JB-4) and sandy loam (JB-5 and JB-6) soils (Greve \& Breuning-Madsen, 1999). A Danish climate profile present in the model was customized to arrive at annual precipitation amounts of 660 and $950 \mathrm{~mm} / \mathrm{year}$, representative for the dry and wet climate subscenarios. For the 2050 scenarios, a climate data set from a French weather station in a temperate maritime climate was modified so that the annual total amount of precipitation matches the wet and dry Danish climate scenarios, thereby yielding a climate profile considered representative for the expected climatic conditions in Denmark in 2050.

\subsubsection{Other agricultural activities}

The soil preparation steps accounted for by the product system model are similar to those described in Hamelin et al. (2012) and will not be described in detail here. In a nutshell, the soil preparation steps accounted for cover ploughing, harrowing, and seedbed harrowing followed by rolling. Harrowing was modeled as spring tine harrowing on a sandy soil, and a rotary harrowing on sandy loam soil. The diesel consumption of these activities was adjusted to reflect Danish conditions according to Damgaard et al. (2001). For sandy soils, a diesel consumption adjustment factor of 0.9 was used in accordance with Hamelin et al. (2012). The same procedure was followed for the other agricultural machinery-related processes: sowing and application of pesticides. Mineral fertilizer was assumed to be applied with a broadcaster and manure was spread using a vacuum tank.

\subsubsection{Allocation}

Allocation was applied to split impacts of processes that result in more than one outputs: growing barley also produces straw, and the manure used as a fertilizer is a side-product of pig farming. 
Dijkman, T. J., Birkved, M., Saxe, H., Wenzel, H., \& Hauschild, M. Z. (2017). Environmental impacts of barley cultivation under current and future climatic conditions. J ournal of Cleaner Production, 140, 644-653. DOI : $10.1016 /$ j.jclepro.2016.05.154

The average price of $1 \mathrm{~kg}$ of barley grains between 2006 and 2010 was DKK 1.11 (Statistics Denmark, 2013). The price for straw in Denmark is typically between DKK 0.15 and 0.25 per kg (Erfaland.dk, 2011), even though prices below DKK 0.40 per kg are discouraged when the straw is sold for energy generation purposes (Hinge \& Maegaard, 2005). Here a straw price of DKK 0.20 per kg was applied. Combined with a mass ratio for harvested grains:harvestable straw of 1.82, the allocation factor for barley grains was calculated to be 0.91 while the straw allocation factor amounts to 0.09. These allocation factors were used for both the 2010 and 2050 scenarios. Pig manure, here used as a fertilizer, is a by-product from pig production. The market price of a finisher pig with an assumed weight of $100 \mathrm{~kg}$ is $\mathrm{DKK} 400$ (Danish Agriculture and Food Council, 2011). The price of pig slurry is DKK 70 per tonne (Hansen \& Tersbøl, 2009), and a pig produces $470 \mathrm{~kg}$ slurry over its lifetime (Hamelin, 2012). Therefore the resulting allocation factor for pig slurry was 0.076 .

\subsubsection{Overview of processes}

An overview of the processes used in this study is found in Supplementary Information 1.

\subsection{Impact Assessment}

Classification and characterization were done at midpoint level using the ReCiPe $(\mathrm{H})$ methodology for the following impact categories: climate change, ozone depletion, terrestrial acidification, freshwater and marine eutrophication, ionizing radiation, particulate matter formation, photochemical oxidant formation, freshwater ecotoxicity, human toxicity, fossil depletion, metal depletion, water depletion, agricultural land occupation, natural land transformation, and urban land occupation. Human and freshwater ecotoxicity impacts from pesticide emissions to air and freshwater were characterized using the consensus model USEtox (Rosenbaum et al., 2008), rather than the toxicity impact categories included in ReCiPe $(\mathrm{H})$. This was done because we found USEtox to be better suited for inclusion of new chemicals. USEtox characterization factors for the pesticides applied in barley cultivation are listed in Table 6. It was assumed that the ReCiPe (H) and USEtox characterization factors can be applied under both 2010 and 2050 climatic circumstances. 
Dijkman, T. J., Birkved, M., Saxe, H., Wenzel, H., \& Hauschild, M. Z. (2017). Environmental impacts of barley cultivation under current and future climatic conditions. Journal of Cleaner Production, 140, 644-653. DOI: $10.1016 /$ j.jclepro.2016.05.154

Table 6: Characterization factors for pesticides used in barley cultivation

\begin{tabular}{|c|c|c|c|c|}
\hline \multirow[b]{2}{*}{ Emission compartment } & \multicolumn{2}{|c|}{$\begin{array}{l}\text { Freshwater ecotoxicity } \\
\left(\text { PAF m }{ }^{3} \text { day } \text { kgemitted }^{-1}\right)\end{array}$} & \multicolumn{2}{|c|}{ 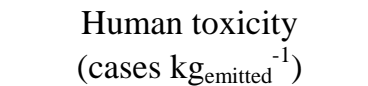 } \\
\hline & $\begin{array}{l}\text { Continental } \\
\text { rural air }\end{array}$ & $\begin{array}{l}\text { Continental } \\
\text { freshwater }\end{array}$ & $\begin{array}{l}\text { Continental } \\
\text { rural air }\end{array}$ & $\begin{array}{l}\text { Continental } \\
\text { freshwater }\end{array}$ \\
\hline Active ingredient & & & & \\
\hline Thifensulfuron methy & $3.56 \cdot 10^{4}$ & $1.29 \cdot 10^{5}$ & $9.44 \cdot 10^{6}$ & $1.15 \cdot 10^{5}$ \\
\hline Tribenuron methyl & $1.55 \cdot 10^{2}$ & $6.80 \cdot 10^{2}$ & $5.34 \cdot 10^{6}$ & $6.66 \cdot 10^{6}$ \\
\hline Pyraclostrobin & $1.33 \cdot 10^{1}$ & $2.40 \cdot 10^{3}$ & $3.07 \cdot 10^{7}$ & $1.89 \cdot 10^{6}$ \\
\hline Epoxiconazole & $4.43 \cdot 10^{2}$ & $2.30 \cdot 10^{4}$ & $8.43 \cdot 10^{6}$ & $4.39 \cdot 10^{5}$ \\
\hline$\lambda$-cyhalotrin & $5.76 \cdot 10^{5}$ & $1.39 \cdot 10^{8}$ & $6.78 \cdot 10^{6}$ & $5.89 \cdot 10^{5}$ \\
\hline
\end{tabular}

Thus, the choice of ReCiPe $(\mathrm{H})$ supplemented with USEtox allows us to conduct a broad assessment of the impacts under current and future climatic circumstances, instead of a selection of impact categories that are selected because these are considered important for agricultural LCA: acidification, climate change, eutrophication, photochemical oxidant formation and resource depletion (see for example Torellas et al., 2012), sometimes supplemented by toxicity impacts (see for example Nemecek et al., 2011) However, environmental impacts that occur as a consequence of agriculture, such as changes in soil quality and biodiversity (Meier et al., 2015), have not been included since no suitable LCIA methodologies capable of accounting for these impacts are available. Moreover, in the case of soil quality, the field is included in the technosphere. As a consequence, changes in soil quality are not environmental impacts affecting the ecosphere.

The characterized results were not normalized. The main purpose of normalization is supporting a further comparison of impacts across impact categories. This is not among the aims of this paper, removing the need for normalization.

\subsection{Sensitivity Analyses}

In the sensitivity analysis, a number of model parameters were tested to determine if, or how, changes in these would affect the conclusions.

First of all, the allocation factors for barley grains and straw for the 2050 scenarios were analyzed. Grain prices in Denmark have shown an increasing trend in the recent decades (Statistics Denmark, 2013). Meanwhile, focus on increasing the share of sustainable energy in the Danish electricity consumption has also led to an increased use of agricultural by-products for electricity generation (Bentsen, 2012). Because the Danish government aims at a fossil fuel free energy system in 2050 (Danish government, 2011) prices for biomass may increase more than grain prices. However, for both grain and straw the price increase cannot be foreseen. Since the relative increase determines the allocation factor of the impacts of barley cultivation, a 'break-even' point was calculated for the scenarios 2050-1 and 
Dijkman, T. J., Birkved, M., Saxe, H., Wenzel, H., \& Hauschild, M. Z. (2017). Environmental impacts of barley cultivation under current and future climatic conditions. J ournal of Cleaner Production, 140, 644-653.

DOI : $10.1016 /$ j.jclepro.2016.05.154

2050-3. 'Break-even' is defined as the allocation factor that would make the environmental impacts of the 2050 climatic circumstances equal those of 2010.

Other model parameters, selected on the basis of their large contribution to the environmental impacts observed from the model results, were increased by $10 \%$ in order to determine how the environmental impacts, would respond to such changes. The following parameters were investigated: yield, share of pig manure in fertilization, and on-farm fuel consumption.

\section{Results}

The potential environmental impacts for the 4 scenarios for barley cultivation in 2010 are presented in Table 7 . To ease the comparison across scenarios, the four rightmost columns show the relative results for each impact category, setting the impact with the highest score to 1 . Figure 1 presents the relative impacts for the four 2050 scenarios, which are in this figure compared to the results for the 2010 scenarios. 
Dijkman, T. J., Birkved, M., Saxe, H., Wenzel, H., \& Hauschild, M. Z. (2017). Environmental impacts of barley cultivation under current and future climatic conditions. J ournal of Cleaner Production, 140, 644-653. DOI : $10.1016 /$ j.jclepro.2016.05.154

Table 7: Characterized impacts for $1 \mathrm{~kg}$ of spring barley at farm gate for the four scenarios modelling the climate of 2010. See Table 1 for the scenario definitions

\begin{tabular}{|c|c|c|c|c|c|c|c|c|c|c|}
\hline \multirow[t]{3}{*}{ Environmental impact category } & \multirow[t]{3}{*}{ Abbreviation } & \multirow[t]{3}{*}{ Unit } & \multicolumn{4}{|c|}{ Environmental impact, characterized } & \multicolumn{4}{|c|}{ Environmental impact, relative $^{1}$} \\
\hline & & & \multicolumn{4}{|c|}{ Scenario } & \multicolumn{4}{|c|}{ Scenario } \\
\hline & & & 1 & 2 & 3 & 4 & 1 & 2 & 3 & 4 \\
\hline Climate change & CC & $\mathrm{kg} \mathrm{CO}$-eq & $3.31 \cdot 10^{-1}$ & $3.31 \cdot 10^{-1}$ & $2.97 \cdot 10^{-1}$ & $2.98 \cdot 10^{-1}$ & 1 & 1 & 0.90 & 0.90 \\
\hline Ozone depletion & OD & kg CFC11-eq & $1.50 \cdot 10^{-8}$ & $1.50 \cdot 10^{-8}$ & $1.54 \cdot 10^{-8}$ & $1.52 \cdot 10^{-8}$ & 0.97 & 0.97 & 1 & 0.99 \\
\hline Acidification, terrestrial & $\mathrm{ACt}$ & $\mathrm{kg} \mathrm{SO}_{2}$-eq & $7.14 \cdot 10^{-3}$ & $7.14 \cdot 10^{-3}$ & $5.84 \cdot 10^{-3}$ & $6.02 \cdot 10^{-3}$ & 1 & 1 & 0.82 & 0.84 \\
\hline Eutrophication, freshwater & EUf & kg P-eq & $2.20 \cdot 10^{-4}$ & $2.20 \cdot 10^{-4}$ & $1.38 \cdot 10^{-4}$ & $1.38 \cdot 10^{-4}$ & 1 & 1 & 0.63 & 0.63 \\
\hline Eutrophication, marine & EUm & kg N-eq & $6.78 \cdot 10^{-3}$ & $5.65 \cdot 10^{-3}$ & $5.14 \cdot 10^{-3}$ & $4.32 \cdot 10^{-3}$ & 1 & 0.83 & 0.76 & 0.64 \\
\hline Ionizing radiation & IOR & kg U235-eq & $6.18 \cdot 10^{-3}$ & $6.18 \cdot 10^{-3}$ & $6.79 \cdot 10^{-3}$ & $6.68 \cdot 10^{-3}$ & 0.91 & 0.91 & 1 & 0.98 \\
\hline Particulate matter formation & PMF & kg PM10-eq & $1.32 \cdot 10^{-3}$ & $1.32 \cdot 10^{-3}$ & $1.16 \cdot 10^{-3}$ & $1.18 \cdot 10^{-3}$ & 1 & 1 & 0.88 & 0.90 \\
\hline Photochemical oxidant formation & POF & kg NMVOC & $1.73 \cdot 10^{-3}$ & $1.73 \cdot 10^{-3}$ & $1.68 \cdot 10^{-3}$ & $1.68 \cdot 10^{-3}$ & 1 & 1 & 0.97 & 0.97 \\
\hline Toxicity, freshwater eco- & TOf & PAF $\mathrm{m}^{3}$ day & $1.50 \cdot 10^{-4}$ & $1.47 \cdot 10^{-4}$ & $1.48 \cdot 10^{-4}$ & $1.71 \cdot 10^{-4}$ & 0.88 & 0.86 & 1 & 1 \\
\hline Toxicity, human & TOh & cases & $1.78 \cdot 10^{-12}$ & $1.77 \cdot 10^{-12}$ & $9.90 \cdot 10^{-13}$ & $9.86 \cdot 10^{-13}$ & 1 & 1 & 0.56 & 0.56 \\
\hline Resource depletion, fossil & RDf & kg oil-eq & $5.07 \cdot 10^{-2}$ & $5.07 \cdot 10^{-2}$ & $5.23 \cdot 10^{-2}$ & $5.23 \cdot 10^{-2}$ & 0.97 & 0.97 & 1 & 0.99 \\
\hline Resource depletion, metal & $\mathrm{RDm}$ & kg Fe-eq & $2.50 \cdot 10^{-2}$ & $2.50 \cdot 10^{-2}$ & $2.88 \cdot 10^{-2}$ & $2.84 \cdot 10^{-2}$ & 0.87 & 0.87 & 1 & 0.98 \\
\hline Resource depletion, water & RDw & $\mathrm{m}^{3}$ & $3.73 \cdot 10^{-1}$ & $3.73 \cdot 10^{-1}$ & $3.57 \cdot 10^{-1}$ & $3.52 \cdot 10^{-1}$ & 0.94 & 0.94 & 1 & 0.99 \\
\hline Agricultural land occupation & LOa & $\mathrm{m}^{2} \mathrm{a}$ & $1.91 \cdot 10^{0}$ & $1.91 \cdot 10^{0}$ & $1.67 \cdot 10^{0}$ & $1.67 \cdot 10^{0}$ & 1 & 1 & 0.87 & 0.87 \\
\hline Natural land transformation & NLT & $\mathrm{m} 2$ & $9.25 \cdot 10^{-5}$ & $9.25 \cdot 10^{-5}$ & $8.49 \cdot 10^{-5}$ & $8.43 \cdot 10^{-5}$ & 1 & 1 & 0.92 & 0.91 \\
\hline Urban land occupation & $\mathrm{LOu}$ & $\mathrm{m}^{2} \mathrm{a}$ & $1.18 \cdot 10^{-2}$ & $1.18 \cdot 10^{-2}$ & $1.16 \cdot 10^{-2}$ & $1.16 \cdot 10^{-2}$ & 1 & 1 & 0.98 & 0.98 \\
\hline
\end{tabular}

1: For the relative results, the highest impact in each category was set to 1 , and the other impacts in that category were expressed as a fraction of the highest impact. 
Dijkman, T. J., Birkved, M., Saxe, H., Wenzel, H., \& Hauschild, M. Z. (2017). Environmental impacts of barley cultivation under current and future climatic conditions. Journal of Cleaner Production, 140, 644-653.

DOI : $10.1016 /$ j.jclepro.2016.05.154

(a)

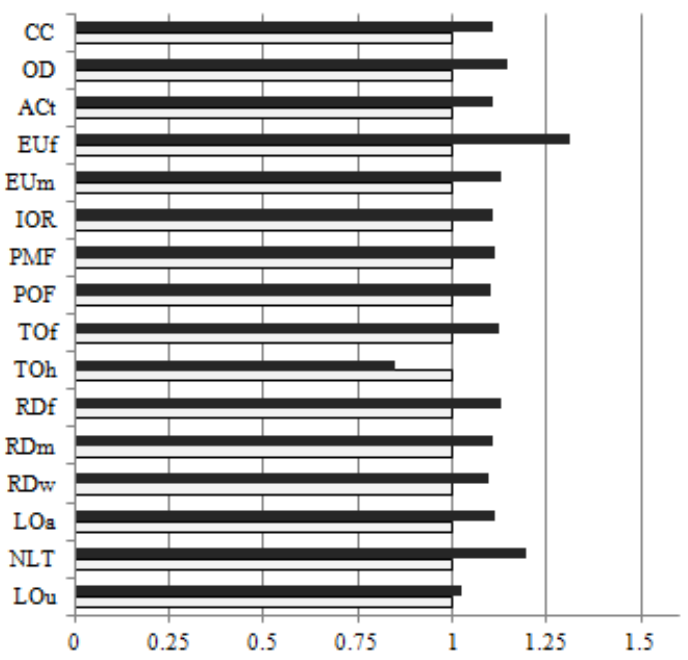

(c)

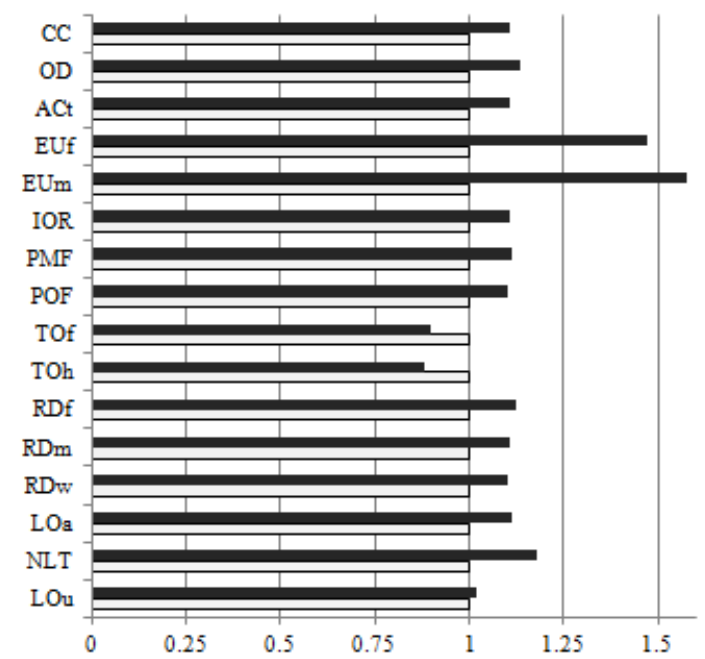

(b)

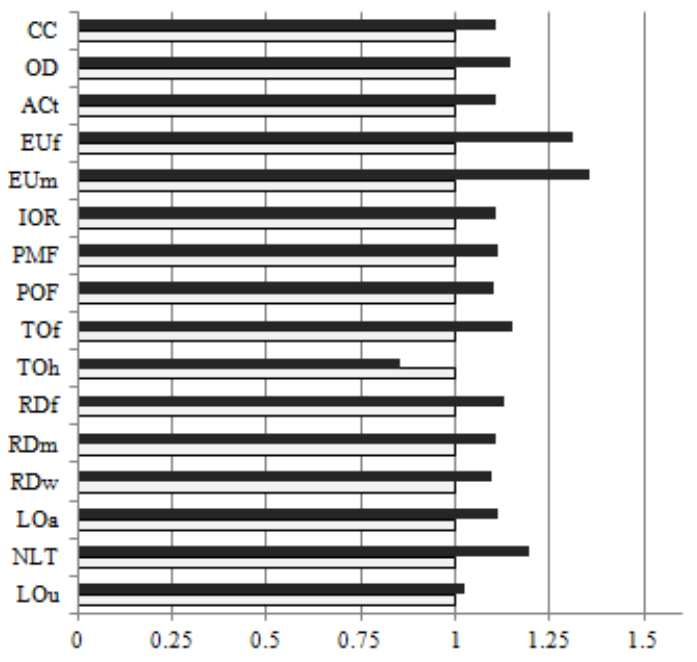

(d)

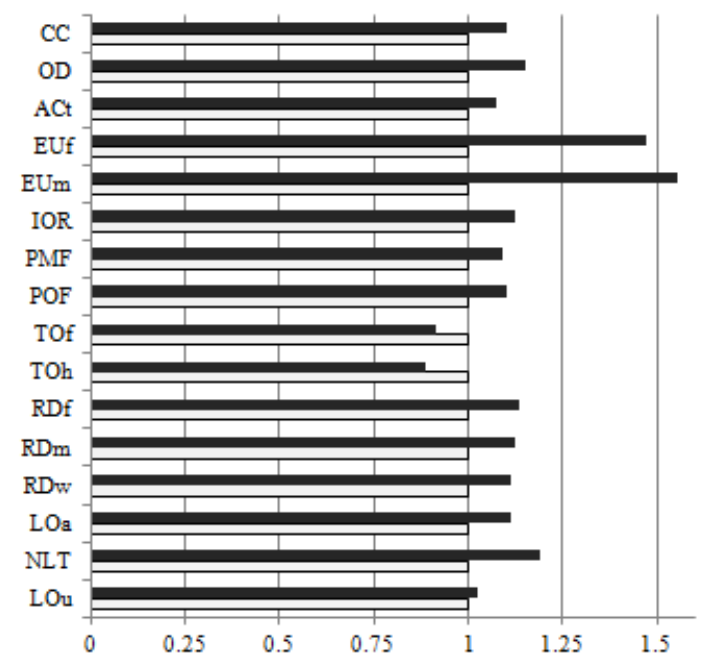

Figure 1: Comparison of characterized impacts between 2010 (white) and 2050 (black) scenarios, with 2010 results indexed at 1. Figure (a) presents subscenario 1, (b) subscenario 2, (c) subscenario 3, (d) subscenario 4. An overview of the scenarios is presented in Table 1, the acronyms are given in Table 7.

\section{Discussion}

\subsection{Impacts under 2010 climate scenarios}

Looking at Table 7, it can be concluded that the variation in environmental burdens arising from the cultivation of barley in Denmark is small, with minimal dependencies on soil and local climate. For the majority of impact categories the larger environmental burden is found for sub-scenarios 1 and 2 (sandy soil), compared to sub-scenarios 3 and 4 (sandy loam soil). This does not come as a surprise: barley cultivation on sandy soil produces lower yields, despite higher fertilizer inputs per hectare. However, for the impact categories ozone depletion, ionizing radiation and those 
Dijkman, T. J., Birkved, M., Saxe, H., Wenzel, H., \& Hauschild, M. Z. (2017). Environmental impacts of barley cultivation under current and future climatic conditions. Journal of Cleaner Production, 140, 644-653. DOI : $10.1016 /$ j.jclepro.2016.05.154

related to resource depletion, the higher environmental impacts are observed for sandy loam soils. In these cases, the use of heavier machinery and/or higher diesel combustion results in larger impacts.

\subsection{Impacts under 2050 climate scenarios}

Overall, the differences between 2010 and 2050 scenarios are in the order of up to $10 \%$, reflecting the changes in the input data for the 2010 and the 2050 scenarios, which typically were in the same order of magnitude. Looking at climate change, the driver for the changes we studied, a positive feedback mechanism is observed: the changes to crop production induced by climate change lead to additional climate change impacts.

The Figures 1a and 1b, barley cultivation on sandy soils, show that all impacts except human toxicity in the 2050 scenarios are higher than in the corresponding 2010 scenarios. In fact, most impacts are approximately $10 \%$ higher in the 2050 scenario compared to the corresponding 2010 scenario, reflecting the predicted $10 \%$ yield decrease in the 2050 scenarios. As a consequence of this yield decrease, more inputs are required to produce $1 \mathrm{~kg}$ of barley. Grain yield is thus an important parameter for explaining the increased level of impacts in 2050 for most of the impact categories.

The explanation for the $>10 \%$ increase in freshwater eutrophication is that while the fertilizer inputs are assumed to remain unchanged, the predicted reduction in biomass yields in 2050 results in an increased P surplus. As P run-off was modelled as a fixed fraction of this surplus, P emissions thus increase resulting in higher freshwater eutrophication impacts. For human toxicity, a reduced impact is observed in 2050. The human toxicity impact is, surprisingly, largely driven by clopyralid emissions during rapeseed cultivation for pig feed. PestLCI 2.0 modelling results showed that these emissions are lower under the 2050 climatic circumstances. This observation is explained by more frequent rainfall in the 2050 climatic circumstances: an assumption in PestLCI 2.0 is that all pesticide washes off from leaf surfaces to soil during the first rainfall event after pesticide application. Thus, more frequent rainfall reduces the air emissions due to volatilization from plant surfaces of clopyralid.

Figures 1c and 1d present the comparison of impact between the 2010 and 2050 climatic scenarios for barley cultivation on sandy loam soils. The trends for these two sub-scenarios are largely the same as observed in the sub-scenarios 20501 and 2050-2, with two exceptions: marine eutrophication and freshwater ecotoxicity impacts. The considerable increase in marine eutrophication is caused by higher N-emissions from sandy loam soils under the 2050 climatic circumstances. The increase on sandy loam soils (50\% increase) is more pronounced than on sandy soils, where emissions were $2 \%$ higher. Freshwater toxicity impacts showed a decrease for the sandy loam soils in the 2050 scenario compared to the 2010 scenario, which contrasts with the increasing impacts on sandy soils (sub-scenarios 1 
Dijkman, T. J., Birkved, M., Saxe, H., Wenzel, H., \& Hauschild, M. Z. (2017). Environmental impacts of barley cultivation under current and future climatic conditions. Journal of Cleaner Production, 140, 644-653.

DOI : $10.1016 /$ j.jclepro.2016.05.154

and 2). The explanation is the removal of a $\lambda$-cyhalotrin application in the 2050 scenario for the sandy loam soils (see Table 5). However, Henriksen et al. (2013) noted that a warmer climate and the resulting consequences for the crop composition is expected to improve conditions for aphids. Depending on the timing of barley cultivation and the effects of climate change on aphid predators, one can therefore speculate about the continuation of $\lambda$-cyhalotrin application in an altered climate. If this pesticide is applied in scenarios 2050-3 and 2050-4, the freshwater ecotoxicity impacts increase approximately $30 \%$ in the 2050 scenarios, ending up $4.7 \%$ and $6.9 \%$ higher than the corresponding 2010 scenarios.

For modelling of the application of pesticides, we followed the approach outlined in Henriksen et al. (2013) and assumed that the presence and intensity of pests under future climatic circumstances in Denmark is similar to the current situation in regions where the climate currently is similar to the expected future climatic circumstances. However, given the difficulties in modelling the response of pests to climate change (Juroszek \& Von Tiedemann, 2011), other assumptions can be made about the future pests and pesticide use. For example, Niero et al. (2015) assume a $25 \%$ increase in the amount of pesticides used in barley production under future climatic circumstances. Had that approach been followed here for (a) barley cultivation alone or (b) for all crops in the product system, larger toxicity impacts would have been calculated. In case (a), the freshwater ecotoxicity and human toxicity results would increase 1.2-4.5 \%, thus not changing the observations made regarding toxicity in the 2050 climatic scenarios. In case (b), the picture would change: in all scenarios, the human toxicity and freshwater ecotoxicity impacts would now be larger under 2050 climatic circumstances than under their 2010 equivalents.

From the results presented in Figure 1, we conclude that the impacts for barley cultivation are higher when the barley is produced under the climatic conditions representative for 2050, compared to the impacts from 2010 scenarios. This result is in accordance with Niero et al. (2015), who found that environmental impacts of barley cultivation increase under worst case future climatic circumstances, except for an optimistic scenario in which the rate of yield improvements of the past four decades are sustained in the future. As concluded in the present study, Niero et al. (2015) found that decreasing yields are the main driver for the increased environmental impacts. The conclusion that the yield has an important role in determining environmental impacts when comparing agricultural products (Cerutti et al., 2013) or production systems (Nemecek et al., 2011, De Backer et al., 2012) when the functional unit is mass-based, is in line with previously published work. In both the current study and the study by Niero et al. (2015) on barley production, the same characterization factors are applied for both the 2010 and the 2050 climatic circumstances. It can, however, be 
Dijkman, T. J., Birkved, M., Saxe, H., Wenzel, H., \& Hauschild, M. Z. (2017). Environmental impacts of barley cultivation under current and future climatic conditions. Journal of Cleaner Production, 140, 644-653. DOI : $10.1016 /$ j.jclepro.2016.05.154

argued that new characterization factors should be calculated for the 2050 scenarios for all impact categories, in order to express changes in the environmental fate and in the effects of emissions as a consequence of altered climatic circumstances. For example, the rates of chemical transformations can expected to be increased under elevated temperatures. Such a task is extensive and beyond the scope of this study, requiring that the cause-effect chains and all inputs of all models used to calculate the characterization factors are adapted to reflect higher temperatures, an altered rainfall patterns, etc.

\subsection{Sensitivity analyses}

The calculation of break-even points for share of impacts allocated to the barley grains is shown in Table 8. Since the impacts obtained for the scenarios based on sandy soils (2050-1 and 2050-2) and sandy loam soils (2050-3 and 2050-4) scenarios were found to be similar, break-even points are shown for just one scenario for each soil type.

The break-even point is the value that the allocation factor should have in the 2050 scenarios to reduce the impacts of the grains to the level of the corresponding 2010 scenario for a given impact category. The baseline allocation factor is 0.91, the break-even point for many impact categories in both scenarios assessed is around 0.83 . To arrive at that allocation factor, the price of straw would have to double, compared to the price of barley grains. There are different factors that can affect the price of both the barley grains and straw. In a Danish context barley is used for malting and as pig feed, the first use being the most financially beneficial for the farmer. Malting requires grains with low protein content, whilst barley grains were found to have increased protein content under elevated $\left[\mathrm{CO}_{2}\right]$ and temperature (Niero et al., 2015). In addition, an increased temperature during grain filling was reported to result in lower fermentable sugar content (DaMatta et al., 2010). Both effects would make barley less suitable for malting, which may result in lower barley grain prices. In contrast, current straw prices are around DKK $0.20 / \mathrm{kg}$, whilst farmers are advised not to sell straw for less than double that price when the straw is to be used for bioenergy purposes. Given that the Danish government aims at having a fossil fuel free energy system in 2050 (Danish government, 2011), prices for straw may increase. Combining both trends, an allocation factor of 0.83 does not seem unrealistic.

In Table 8, some of the impact categories show a break-even point $>1$. Since an allocation factor of 1 means that all impacts are allocated to the grains, in cases the allocation factor is $>1$ the environmental impacts of cultivating barley under 2050 climate circumstances are always lower than in the 2010 climate scenarios. 
Dijkman, T. J., Birkved, M., Saxe, H., Wenzel, H., \& Hauschild, M. Z. (2017). Environmental impacts of barley cultivation under current and future climatic conditions. Journal of Cleaner Production, 140, 644-653. DOI : $10.1016 /$ j.jclepro.2016.05.154

Table 8: Calculation of break-even points for the allocation factor between straw and barley grains

\begin{tabular}{llcc}
\hline Impact category & & \multicolumn{2}{c}{ Scenario } \\
& & $2050-1$ & $2050-3$ \\
\hline Climate change & & 0.83 & 0.84 \\
Ozone depletion & terrestrial & 0.83 & 0.83 \\
Acidification & freshwater & 0.82 & 0.82 \\
Eutrophication & marine & 0.69 & 0.62 \\
& & 0.81 & 0.58 \\
Ionizing radiation & 0.83 & 0.83 \\
Particulate matter formation & 0.82 & 0.82 \\
Photochemical oxidant formation & 0.83 & 0.83 \\
Toxicity & freshwater ecotoxicity & 0.89 & $>1$ \\
& human & $>1$ & $>1$ \\
Resource depletion & fossil & 0.83 & 0.83 \\
& metal & 0.82 & 0.82 \\
\multirow{2}{*}{ Land use related impacts } & agricultural land occupation & 0.83 & 0.83 \\
& natural land transformation & 0.87 & 0.82 \\
& urban land occupation & 0.89 & 0.86 \\
\hline
\end{tabular}

Because the sensitivity analysis results were similar for the different scenarios, Table 9 only presents results for scenario 2010-1. In the table, the sensitivity is expressed as the percentage change in output resulting from a $10 \%$ increase in input parameter for all impact categories.

Table 9: Sensitivity analysis for scenario 2010-1, showing the change in impacts (\%) in the impact categories when the input parameters (allocation factor assigned to pig manure, fraction of fertilization done with manure, on-farm fuel consumption, yield) are increased $10 \%$.

\begin{tabular}{llcccc}
\hline Impact category & & & & & \\
& & Allocation & Fertilization & Fuel cons. & Yield \\
\hline Climate change & & 0.63 & -2.1 & 1.5 & -8.7 \\
Ozone depletion & & 0.52 & -3.5 & 3.8 & -11 \\
Acidification & terrestrial & 0.21 & 5.1 & 0.1 & -9.0 \\
Eutrophication & freshwater & 0.13 & -0.057 & 0.0047 & -35 \\
& marine & 0.22 & 0.17 & 0.018 & -1.4 \\
Ionizing radiation & & 0.38 & -2.9 & 0.46 & -8.7 \\
Particulate matter formation & 0.33 & 2.8 & 0.59 & -9.1 \\
Photochemical oxidant formation & freshwater ecotoxicity & 0.39 & -0.59 & 0.19 & -8.3 \\
Toxicity & human & 6.4 & 0 & 0 & -3.6 \\
\multirow{2}{*}{ Resource depletion } & fossil & 9.4 & 0 & 0 & -0.59 \\
& metal & 0.61 & -3.27 & 3.08 & -10 \\
Land use related impacts & agricultural land occupation & 0.18 & -0.007 & 0.0002 & -9.0 \\
& nater & 0.23 & -2.41 & 0.069 & -8.7 \\
& natural land transformation & 8.6 & -1.3 & 2.8 & -7.1 \\
& urban land occupation & 0.17 & -0.62 & 0.072 & -1.8 \\
\hline
\end{tabular}

Table 9 illustrates again that the results are highly sensitive to changes in yields of barley cultivation. In this study, based on different modelling results presented by Doltra et al. (2012), it was assumed that the barley yields will 
Dijkman, T. J., Birkved, M., Saxe, H., Wenzel, H., \& Hauschild, M. Z. (2017). Environmental impacts of barley cultivation under current and future climatic conditions. Journal of Cleaner Production, 140, 644-653. DOI : $10.1016 /$ j.jclepro.2016.05.154

decrease with $10 \%$ in the climate prevalent in Denmark in 2050. The yield decrease in the scenarios modelled by these authors varied between 4 and 18\%, similar to results found by other authors: Borgesen and Olesen (2011) found a decrease in yields for wheat of $10 \%$, Clausen et al. (2012) found a yield reduction of $14 \%$ (which was however not statistically significant). It can be shown that, even when assuming a yield decrease of $4 \%$ in under the climatic circumstances of 2050, the environmental impacts are higher than in the current climate (except human toxicity when using sub-scenario 1 as a basis for this calculation). However, it may very well be that the yield decrease estimates used for this study may be conservative, because the effects of an increased ozone atmospheric concentration have not been included. Clausen et al. (2011) suggest that increasing ozone concentrations will reduce yields even more.

\subsection{Mitigation options}

In this study we assessed the environmental impacts of barley cultivation under 2050 climatic conditions. We have, however, not attempted to model the 2050 society and its policies. The reason for this modelling approach is our intention to study the effects of climate change on barley cultivation rather than the effect of human efforts to mitigate environmental impacts. However, policies can be expected to change in the future, and mitigation actions may be taken. Firstly, because it was found that most environmental impacts increase as a consequence of decreasing yield, changing to other barley cultivars may reduce the impacts under future climatic circumstances. A switch to a barley variety with a longer growing period would result in more biomass being accumulated, as well as in lower nitrogen emissions (Doltra et al., 2012).

Secondly, from Figure 1 it can be seen that eutrophication impacts increase more than the other impact categories for most scenarios under the 2050 climatic circumstances. Eutrophication related to fertilizer use in agriculture already is a prioritized environmental challenge in Denmark (Kaas et al., 1999). Therefore additional measures may be taken in the future, which are not considered in this study. For example, Doltra et al. (2012) discuss altered management of catch crops to reduce $\mathrm{N}$ leaching, as well as switching to barley cultivars that have a longer growing period. Jeppesen $e t$ al. (2009) moreover suggested the re-establishment of riparian buffer zones or buffer zones in combination with highly Padsorbing substrates to prevent P runoff to freshwater. In addition, pesticide consumption may decrease in the future, for example by a more targeted application of herbicides to the individual weed plants instead of the current practice of applying pesticides to an entire field (Djursing, 2013).Toxicity impacts may be reduced further by introducing new pesticides, which are more targeted and have a higher target organism toxicity and lower general (non-target organism) have lower toxicity potentials than the pesticides currently applied. 
Dijkman, T. J., Birkved, M., Saxe, H., Wenzel, H., \& Hauschild, M. Z. (2017). Environmental impacts of barley cultivation under current and future climatic conditions. Journal of Cleaner Production, 140, 644-653.

DOI : $10.1016 /$ j.jclepro.2016.05.154

\section{Conclusion}

The potential environmental impacts modeled for the cultivation of $1 \mathrm{~kg}$ of barley in the climatic circumstances of 2050, compared to those of 2010, were found to be higher in all impact categories assessed, except toxicity. This increase was found to be driven mainly by a reduction in yield under future climate conditions. Modelling of current and future climatic circumstances was done for four sub-scenarios, showing minor differences between these sub-scenarios. The conclusion that impacts are higher under future climatic circumstances is valid when assuming that the environmental impacts of barley cultivation, producing both grains and straw, are assigned to the grains using an allocation factor of 0.91. A sensitivity analysis showed that a of doubling the straw price relative to the grain price changes the allocation of impacts in such a way that lower impacts are found for the 2050 climate scenario. Effects of technological developments or policy changes were not considered in defining the future climate scenarios, but a switch to higher yielding cultivars could reduce environmental impacts, as would measures to mitigate nutrient leaching and the introduction of new pesticides.

\section{Acknowledgements}

The authors would like to thank the project 'Development of genetically modified cereals adapted to the increased $\mathrm{CO}_{2}$ levels of the future' funded by the Danish Ministry of Food, Agriculture and Fisheries for funding this project. Furthermore, we would like to thank Jørgen E. Olesen, Lorie Hamelin and Maria Nordborg for their help with the inventory analysis, and Peter Fantke and Anders Bjørn for their help in deriving characterization factors for pesticide ingredients needed to complete this study.

\section{References}

Ardente F, Cellura M (2012) Economic allocation in life cycle assessment. J Ind Ecol 16: 387-398.

Bentsen, NS (2012) Bioenergi: Udvikling, anvendelse og miljømæssige forhold (Bioenergy: development, use and environment, in Danish) Det Etiske Råd, Copenhagen (Denmark). Retrieved from http://www.etiskraad.dk/Udgivelser/ /media/bibliotek/rapporter/2012/Bioenergi-udvikling-anvendelse-ogmiljoemaessige-forhold-bilag.pdf (28 ${ }^{\text {th }}$ August 2013).

Brankatschk G, Finkbeiner M (2014) Application of the Cereal Unit in a new allocation procedure for agricultural life cycle assessments. J Cleaner Prod 73: 72-79.

Børgesen CD, Olesen JE (2011) A probabilistic assessment of climate change impacts on yield and nitrogen leaching from winter wheat in Denmark. Nat Hazards Earth Syst Sci 11: 2541 - 2553.

Cerutti AK, Bruun S, Donno D, Beccaro GL, Bounous G (2013) Environmental sustainability of traditional foods: the case of ancient apple cultivars in Northern Italy assessed by multifunctional LCA. J Cleaner Prod 52: 245-252.

Clausen SK, Frenck G, Linden LG, Mikkelsen TN, Lunde C, Jørgensen RB (2011) Effects of single and multifactor treatments with elevated temperature, $\mathrm{CO}_{2}$ and ozone on oilseed rape and barley. J Agron Crop Sci 197: 442-453.

Cook J, Nuccitelli D, Green SA, Richardson M, Winkler B, Painting R, Way R, Jacobs P, Skuce A (2013) Quantifying the consensus on anthropogenic global warming in the scientific literature. Environ. Res. Lett. 8: 024024. 
Dijkman, T. J., Birkved, M., Saxe, H., Wenzel, H., \& Hauschild, M. Z. (2017). Environmental impacts of barley cultivation under current and future climatic conditions. Journal of Cleaner Production, 140, 644-653.

DOI : $10.1016 /$ j.jclepro.2016.05.154

Dalgaard T, Halberg N, Porter JR (2001) A model for fossil energy use in Danish agriculture used to compare organic and conventional farming. Agric Ecosystems \& Environm 87: 51-65.

DaMatta FM, Grandis A, Arenque BC, Buckeridge MS (2010) Impacts of climate changes on crop physiology and food quality. Food Res Int 43:1814-1823.

Danish Agriculture and Food Council (2011) Pig Research Center. Annual report 2010. Danish Agriculture and Food Council, Copenhagen (Denmark).

Danish Government (2011) Our future energy. Retrieved from http://www.cphcleantech.com/media/1465822/our_future_energy.pdf (24 ${ }^{\text {th }}$ September 2013).

Danish Ministry of Food, Agriculture and Fisheries (2009) The Danish Plant Directorate. Vejledning om gødskningsog harmoniregler. Planperioden 1. august 2009 til 31. juli 2010. (In Danish) Danish Ministry of Food, Agriculture and Fisheries, Copenhagen (Denmark).

De Backer E, Aertsens J, Vergucht S, Stuerbaut W (2009) Assessing the ecological soundness of organic and conventional agriculture by means of life cycle assessment (LCA): A case study of leek production. Brit Food J 111: 1028-1061.

Dijkman TJ, Birkved M, Hauschild MZ (2012). PestLCI 2.0: A second generation model for estimating emissions of pesticides from arable land in LCA. Int J Life Cycle Assess 17(8): 973-986.

Dijkman TJ (2014) Modelling of pesticide emissions for Life Cycle Inventory Analysis. PhD thesis, Techical University of Denmark, Kongens Lyngby (Denmark).

Djursing T (2013) Droner spotter ukrudt i danske marker (Drones spot weeds in Danish fields, in Danish). Retrieved from http://ing.dk/artikel/droner-spotter-ukrudt-i-danske-marker-161076 (28 $8^{\text {th }}$ August 2013).

Doltra J, Lægdsmand M, Olesen JE (2012) Impacts of projected climate change on productivity and nitrogen leaching of crop rotations in arable and pig farming systems in Denmark. J Agric Sci, doi:10.1017/S0021859612000846.

Ecoinvent centre (2007): Ecoinvent reports no. 1-25. Swiss Centre for Life Cycle Inventories, Dübendorf (Switzerland).

Erfaland.dk (2011) Pris på halm (Price of straw, in Danish) retrieved from https://erfaland.dk/Planteavl/198-Pris-pahalm.html (28 ${ }^{\text {th }}$ August 2013).

Finnveden G, Hauschild MZ, Ekvall T, Guinée J, Heijungs R, Hellweg S, Koehler A, Pennington D, Suh S (2009) Recent developments in Life Cycle Assessment. J Environ Manage 91(1): 1-21.

Gasol CM, Salvia J, Serra J, Anton A, Sevigne E, Rieradevall J, Gabarrell X (2012) A life cycle assessment of biodiesel production from winter rape grown in Southern Europe. Biomass Bioenerg 40: 71-81.

Gregory PJ, Johnson SN, Newton AC, Ingram JSI (2009) Integrating pests and pathogens into the climate change/food security debate. J Exp Bot 60: 2827-2838.

Greve MH, Breuning-Madsen H (1999) Soil mapping in Denmark. European Soil Bureau. Retrieved from http://139.191.1.96/ESDB_Archive/eusoils_docs/esb_rr/n09_soilresources_of_europe/Denmark.pdf $\left(27^{\text {th }}\right.$ August, 2013).

Hamelin L, Jørgensen U, Petersen BM, Olesen JE, Wenzel H (2012) Modelling the carbon and nitrogen balances of direct land use changes from energy crops in Denmark: a consequential life cycle inventory. GCB Bioenerg 4: 889907.

Hamelin L (2013) Carbon management and environmental consequences of agricultural biomass in a Danish renewable energy strategy. $\mathrm{PhD}$ thesis. University of Southern Denmark, Odense (Denmark).

Hansen BV, Tersbøl M (2009) Udnyttelse af biogas i økologisk grønsagsproduktion (use of biogas in ecological vegetable production, in Danish). Retrieved from

https://www.landbrugsinfo.dk/Energi/Biogas/Sider/PLK09_res_H2_2_B_V_Hansen.pdf?download=true $\left(28^{\text {th }}\right.$ August 2013).

Henriksen HJ, Rosenbom A, Keur P van der, Olesen JE, Jørgensen LJ, Kjær J, Sonnenborg T, Christensen OB (2013) Prediction of climatic impacts on pesticide leaching to the aquatic environments: evaluation of direct and indirect (crop rotations, crop management, and pesticide use) climate change effects of pesticide leaching in a regulatory perspective for two Danish cases. Miljøstyrelsen, Copenhagen (Denmark).

Hinge J, Maegaard E (2005) Prisen på halm til kraftvarme (The price of straw for combined heat and power, in Danish). Dansk Landbrugsrådgivning, Aarhus (Denmark). 
Dijkman, T. J., Birkved, M., Saxe, H., Wenzel, H., \& Hauschild, M. Z. (2017). Environmental impacts of barley cultivation under current and future climatic conditions. Journal of Cleaner Production, 140, 644-653.

DOI : $10.1016 /$ j.jclepro.2016.05.154

International Standards Organization (2006). ISO 14040:2006 - Environmental management, Life cycle assessment, principles and framework. CEN, Brussels (Belgium).

IPCC, 2007. Climate Change 2007: Impacts, adaptation and vulnerability. Contribution of Working Group II to the Fourth Assessment Report of the Intergovernmental Panel on Climate Change. Cambridge University Press, Cambridge (United Kingdom).

Jeppesen E, Kronvang B, Meerhoff M, Søndergaard M, Hansen KM, Andersen HE, Lauridsen TL, Liboriussen L, Bekioglu M, Özen A, Olesen JE (2009) Climate change effects on runoff, catchment phosphorus loading and lake ecological state, and potential adaptations. J Environ Qual 38: 1930-1941.

Jeppesen E, Kronvang B, Olesen JE, Audet J, Søndergaard M, Hoffmann CC, Andersen HE, Lauridsen TL, Liboriussen L, Larsen SE, Beklioglu M, Meerhoff M, Özen A, Özkan K (2011) Climate change effect on nitrogen loading from cultivated catchments in Europe: implications for nitrogen retention, ecological stat of lakes and adaptation.

Juroszek P, Von Tiedemann A (2011) Potential strategies and future requirements for plant disease management under a changing climate. Plant Pathol 60: 100-112.

Kaas H, Moestrup Ø, Larsen J, Henriksen P (1999) Giftige alger of algeopblomstringer (Toxic algae and algal blooms)(In Danish). Danish Ministry of Environment and Energy, Copenhagen (Denmark). Retrieved from http://www2.dmu.dk/1_viden/2_Publikationer/3_temarapporter/rapporter/87-7772-476-3.PDF (28 ${ }^{\text {th }}$ August 2013).

Meier MS, Stoessel F, Jungbluth N, Juraske R, Schader C, Stolze M (2015) Environmental impacts of organic and conventional agricultural products: Are the differences captured by life cycle assessment? J Environ Manage 149: 193-208.

Mortensen, JR (1986) Drainage in Denmark: Developments and prospects for the future. Proceedings in Symposium 25th International Course on Land Drainage, Twenty-Five Years of Drainage Experience, International Institute for Land Reclamation and Improvement(ILRI) and International Agricultural Centre (IAC), Wageningen, The Netherlands.

Nemecek T, Dubois D, Huguenin-Elie O, Gaillard G (2011) Life cycle assessment of Swiss farming systems: I. Integrated and organic farming. Agr Syst 104: 217-232.

Nielsen OK, Mikkelsen MH, Hoffmann L, Gyldenkærne S, Winther M, Nielsen M, Fauser P, Thomsen M, Plejdrup MS, Albrektsen R, Hjelgaard K, Bruun HG, Johannsen VK, Nord-Larsen T, Bastrup-Birk A, Vesterdal L, Møller IS, Rasmussen E, Arfaoui K, Baunbæk L, Hansen MG (2011) Denmark’s national inventory report 2011: Emission inventories 1990-2009 submitted under the United Nations Framework Convention on Climate Change and the Kyoto Protocol. National Environmental Research Institute, Aarhus University, Aarhus (Denmark).

Niero M, Ingvordsen CH, Peltonen-Sainio P, Jalli M, Lyngkjær MF, Hauschild MZ, Jørgensen RB (2015) Eco-efficient production of spring barley in a changed climate: A Life Cycle Assessment including primary data from future climate scenarios. Agr Syst136: 46-60.

PE-LBP (2008) GaBi 4 Software-system and databases for life cycle engineering, compilation 4.4.142.1. PE, LBP: Stuttgart, Echterdingen (Germany).

Reckmann K (2013) Life Cycle Assessment of pork especially emphasising feed and pig production. PhD thesis. Christian-Albrechts-Universität, Kiel (Germany).

Rosenbaum RK, Bachmann TM, Gold LS, Huijbregts MAJ, Jolliet O, Juraske R, Koehler A, Larsen HF, MacLeod M, Margni M, McKone TE, Payet J, Schuhmacher M, Meent D van de, Hauschild MZ (2008) USEtox: the UNEPSETAC toxicity model: recommended characterisation factors for human toxicity and freshwater ecotoxicity in life cycle impact assessment. Int J Life Cycle Assess 13: 532-546.

Statistics Denmark (2013) Kapitelstakster efter kornart, kapitelstaksområder og tid. Retrieved from www.statistikbanken.dk/KAPIT1 (2 ${ }^{\text {nd }}$ July 2013).

Torellas M, Antón A, López JC, Baeza EJ, Parra JP, Muñoz P, Montero JI (2012) LCA of a tomato crop in a multitunnel greenhouse in Almeria. Int J Life Cycle Assess 17: 863-875. 